\title{
Radiosensitizing potential of the selective cyclooygenase-2 (COX-2) inhibitor meloxicam on human glioma cells
}

\author{
Irene V. Bijnsdorp · Jaap van den Berg • \\ Gitta K. Kuipers · Laurine E. Wedekind • \\ Ben J. Slotman · Johannes van Rijn · M. Vincent M. Lafleur • \\ Peter Sminia
}

Received: 21 November 2006/ Accepted: 28 March 2007/Published online: 20 April 2007

(C) Springer Science+Business Media B.V. 2007

\begin{abstract}
The COX-2 protein is frequently overexpressed in human malignant gliomas. This expression has been associated with their aggressive growth characteristics and poor prognosis for patients. Targeting the COX-2 pathway might improve glioma therapy. In this study, the effects of the selective COX-2 inhibitor meloxicam alone and in combination with irradiation were investigated on human glioma cells in vitro. A panel of three glioma cell lines (D384, U87 and U251) was used in the experiments from which U87 cells expressed constitutive COX-2. The response to meloxicam and irradiation (dose-range of 0 6 Gy) was determined by the clonogenic assay, cell proliferation was evaluated by growth analysis and cell cycle distribution by FACS. 24-72 h exposure to $250-750 \mu \mathrm{M}$ meloxicam resulted in a time and dose dependent growth inhibition with an almost complete inhibition after $24 \mathrm{~h}$ for all cell lines. Exposure to $750 \mu \mathrm{M}$ meloxicam for $24 \mathrm{~h}$ increased the fraction of cells in the radiosensitive $\mathrm{G}_{2} / \mathrm{M}$ cell cycle phase in D384 (18-27\%) and U251 (17-41\%) cells. $750 \mu \mathrm{M}$ meloxicam resulted in radiosensitization of D384 (DMF:2.19) and U87 (DMF:1.25) cells, but not U251 cells (DMF:1.08). The selective COX-2 inhibitor meloxicam exerted COX-2 independent growth inhibition and radiosensitization of human glioma cells.
\end{abstract}

Keywords COX-2 inhibitor - Meloxicam - Growth inhibition · Radiosensitization · Human Glioma cells

I. V. Bijnsdorp · J. van den Berg · G. K. Kuipers .

L. E. Wedekind · B. J. Slotman · J. van Rijn .

M. V. M. Lafleur · P. Sminia $(\square)$

Department of Radiation Oncology, Division Radiobiology, VU

University Medical Center, Van der Boechorststraat 7,

Amsterdam 1081 BT, The Netherlands

e-mail: p.sminia@vumc.nl

\section{Introduction}

Malignant gliomas account for approximately $30 \%$ of all intracranial tumors, with glioblastoma multiforme to be the most frequent and aggressive type. For many years, surgical resection followed by radiation therapy has been the standard treatment for gliomas, resulting in a median survival of less than 1 year after initial diagnosis [1-3]. Since the study of Stupp et al. [4], showing a significant prolongation of survival by additional administration of temozolomide, the new standard of care for glioblastoma multiforme now consists of surgery, radiotherapy and temozolomide [4]. However, regardless of treatment, almost all of these patients ultimately succumb to their disease. Further optimization of therapy is required.

The cyclooxygenase (COX) enzyme exists in two main isoforms, COX-1 and COX-2. COX-1 is constitutively expressed in most tissue types and plays a role in housekeeping functions. COX-2 expression is low in most normal tissues and can be upregulated under various pathological conditions and also by irradiation. Overexpression of COX-2 has been found to be important in the development of several human tumor types (e.g. colon, gastric, pancreatic) [5], including gliomas [6] and has been associated with high tumor aggressiveness and poor patients' prognosis $[7,8]$. The COX-2 protein is overexpressed in the majority of gliomas, therefore it is considered to be an attractive therapeutic target $[6,8,9]$.

In recent years, drugs with high affinity to COX-2 and low affinity to COX-1, the so-called selective COX-2 inhibitors, have become available. An advantage of this selective affinity is that COX-1 mediated processes are not affected. Therewith, these compounds show a low probability of the occurrence of side effects like gastroulceritis, dyspepsia, or even acute renal failure. Selective inhibitors of COX-2 are 
prescribed for various inflammatory diseases (e.g. arthritis). The anti-tumor effect of selective COX-2 inhibitors, reported both in vitro and in vivo experimental studies [10-12], supported the introduction of these compounds in the clinic. However, the mechanism of action of these inhibitors is not well understood. Angiogenesis regulation, inhibition of cell proliferation as well as apoptosis induction have been reported to be involved in their anti-tumor effect $[5,13,14]$. Interestingly, selective COX-2 inhibitors also demonstrated to act as a radiosensitizer [5, 15-21]. The selective COX-2 inhibitor meloxicam has been shown to inhibit cell proliferation of different cancer cell lines and animal tumors [10, 12, 22-25]. However, no data are available yet on glioma cells. Differences in the profiles between meloxicam and other selective COX-2 inhibitors are explained by its different chemical structure and its unique pharmacological action on COX-2. The underlying molecular mechanism of the anti-inflammatory action of many COX-2 inhibitors is quite well understood, but it is not clear how meloxicam exerts its anticancer effect. Since gliomas represent a group of heterogeneous tumors, and often overexpress COX-2 [6, 9], a better understanding of the basic biology of gliomas and on the response to $\mathrm{COX}-2$ inhibition might contribute to the improvement of glioma therapy.

The objective of the present study was to determine the effectiveness of the COX-2 inhibitor meloxicam alone and in combination with irradiation on cell proliferation, cell survival and radiosensitization on human glioma cell lines, with different COX-2 protein expression levels.

\section{Materials and methods}

\section{Cell culture}

The established human glioma cell line U87 was obtained from the American Type Culture Collection. U251 cells were isolated from a glioblastoma multiforme specimen [26] and D384 cells were cloned from a cell line derived from an astrocytoma [27]. Both U251 and D384 are established cell lines and were kindly provided by Dr. C. H. Langeveld (Dept. Pharmacology, Vrije Universiteit, Amsterdam, The Netherlands) [27]. All cell lines were confirmed to be mycoplasma free and cultured in DMEM supplemented with $10 \%$ fetal calf serum, $2 \%$ glutamine, $100 \mathrm{IU} / \mathrm{ml}$ penicillin, and $100 \mathrm{IU} / \mathrm{ml}$ streptomycin. Cells were grown as monolayers in $25 \mathrm{~cm}^{2}$ culture flasks and were maintained in a humidified $7 \% \mathrm{CO}_{2}$ atmosphere at $37^{\circ} \mathrm{C}$.

Growth assay

$1.10^{5}$ (D384 and U251) or $1.10^{6}$ (U87) cells/flask were plated, a density that enables linear growth. Cells were given $24 \mathrm{~h}$ to attach to the bottom of the culture flask, after which cells were exposed to 250,500 and $750 \mu \mathrm{M}$ of meloxicam (Boehringer Ingelheim, Germany) or vehicle (0.38\% DMSO). Duplicate culture flasks of each day were trypsinized and counted each day for a maximum of 3 days using coulter counter (Coulter ${ }^{\circledR} \mathrm{Z}^{\mathrm{TM}}$ series).

\section{Clonogenic assay}

Subconfluently growing D384, U251 and U87 cells were exposed to $750 \mu \mathrm{M}$ meloxicam or vehicle $(0.38 \%$ DMSO) for $24 \mathrm{~h}$ and irradiated with single doses of $\gamma$-radiation $(0$ 6 Gy) using a ${ }^{60}$ Co source (Gammacell 200, Atomic Energy of Canada Ltd). 150-5000 cells/flask were plated immediately after irradiation for colony-forming ability in medium without meloxicam. After 10 days, colonies were fixed with $100 \%$ ethanol and stained with $10 \%$ Giemsa solution. Colonies containing more than 50 cells were counted. Cell survival curves were estimated after normalization for cytotoxicity induced by meloxicam alone. Data from three independent experiments were combined and the average survival levels were fitted by least squares regression using the linear quadratic model. The Dose Modifying Factor (DMF) (the ratio of the radiation dose plus vehicle and the radiation dose plus meloxicam) was estimated at a surviving fraction (SF) of 0.5. Survival curves were analysed using Statistical Package for Social Sciences (SPSS; Chicago, IL, USA) statistical software as previously described by van Bree et al. [28].

Fluorescence-activated cell sorter (FACS) analysis of cell cycle distribution

After treatment of $5.10^{5}$ cells/flask with vehicle or 250,500 and $750 \mu \mathrm{M}$ meloxicam, cells were trypsinized and resuspended in fresh medium. Cells were washed twice in PBS, centrifuged for $4 \mathrm{~min}$ at $1000 \mathrm{rpm}$, and fixed with $70 \%$ ethanol. Subsequently, cells were incubated with RNAseA $(0.25 \mathrm{mg} / \mathrm{ml})$ for $20 \mathrm{~min}$ at room temperature and stained with propidium iodide $(0.1 \mathrm{mg} / \mathrm{ml})$ for $30 \mathrm{~min}$ in dark on ice. DNA content of the cells was analyzed by FACS (Becton Dickinson) with an acquisition of 50,000 events.

\section{Western blotting}

After $24 \mathrm{~h}$ treatment with vehicle or $750 \mu \mathrm{M}$ meloxicam, cells were scraped in ice-cold PBS and collected for treatment with $25 \mu$ lysis buffer $(50 \mathrm{mM}$ Tris/HCL, $1 \%$ NP40, 0.5\% Na-deoxycholate, $150 \mathrm{mM} \mathrm{NaCl}, 0.05 \%$ SDS, and 1:1000 pefablock) to obtain whole cell lysates. Cell lysates were kept on ice for $1 \mathrm{~h}$ and centrifuged at $14,000 \mathrm{~g}$ at $4^{\circ} \mathrm{C}$ for $10 \mathrm{~min}$. The protein concentration of the supernatant was measured using the Bio-Rad Assay 
(BioRad Laboratories, Germany) according to the manufacturer's instructions. A total of $100 \mu \mathrm{g}$ protein was subjected to $7.5 \%$ SDS-polyacrylamide gel electrophoresis and transferred to a PVDF membrane (Immobilon-P, Millipore). Membrane was blocked in 5\% non-fat milk in TBST (Tris buffered saline, $0.1 \%$ Tween 20 ) for $1 \mathrm{~h}$ at room temperature. Subsequently, the membrane was incubated with the primary antibody (1:1000 mouse- $\alpha$-COX-2 monoclonal antibody, Cayman Chemical, USA) in TBST (with $0.5 \%$ non-fat milk) overnight at $4{ }^{\circ} \mathrm{C}$. The blot was washed 3 times in TBST (with $0.5 \%$ non-fat milk) and incubated with the secondary antibody (1:1000 goat- $\alpha$ mouse-HRP, DAKO Cytomation, Denmark) in TBST (with $0.5 \%$ non-fat milk) for $1 \mathrm{~h}$ at room temperature. After incubation, the membrane was washed in TBST (with $0.5 \%$ non-fat milk) and developed using an ECL system (Amersham Pharmacia, England) on a hyperfilm (Amersham Bioscience, England).

\section{Results}

Effect of meloxicam on cell growth and cell survival

Meloxicam exposure to D384, U87 and U251 cells resulted in a time and dose-dependent growth inhibitory response (Fig. 1). An almost complete growth arrest was induced after exposure to $750 \mu \mathrm{M}$ meloxicam, which remained arrested for up to 3 days. After 24 h of treatment of D384,
U87 and U251 cells with $750 \mu \mathrm{M}$ meloxicam the surviving fraction was $0.57,0.81$ and 0.74 , respectively.

Combination of meloxicam with irradiation

To determine the radiosensitizing potential of meloxicam, cells were incubated for $24 \mathrm{~h}$ with $750 \mu \mathrm{M}$ meloxicam and then irradiated. Cell survival curves (Fig. 2) show that meloxicam treatment enhanced the radiation response of D384 cells (DMF of 2.19, $P<0.01$ ) and of U87 cells (DMF of $1.25, P<0.01$ ), but not that of $\mathrm{U} 251$ cells (DMF of 1.08 , n.s.).

\section{COX-2-protein expression}

COX-2 protein expression levels were assessed to determine whether or not the growth inhibition and radioenhancement after meloxicam treatment were related to COX-2. Subconfluently growing D384 and U251 cells did not show COX-2 expression. U87 cells expressed COX-2 constitutively at a level exceeding the $10 \mathrm{ng}$ reference standard (Fig. 3).

Cell cycle distribution

The effect of meloxicam on cell cycle distribution was analyzed by flow cytometry. As illustrated in the DNA histograms in Fig. 4, both D384 and U251 cells accumulated in the $G_{2} / M$ phase after $24 \mathrm{~h}$ of treatment with
Fig. 1 Dose-dependent growth inhibition after meloxicam exposure. Subconfluently growing D384, U87 and U251 cells were exposed to vehicle (0.38\% DMSO) (匹), or to $250 \mu \mathrm{M}(\mathbf{\Delta}), 500 \mu \mathrm{M}(\boldsymbol{\nabla})$, and $750 \mu \mathrm{M}(\bullet)$ meloxicam for depicted exposure times. Error bars represent SD of three independent experiments and are indicated for each data point
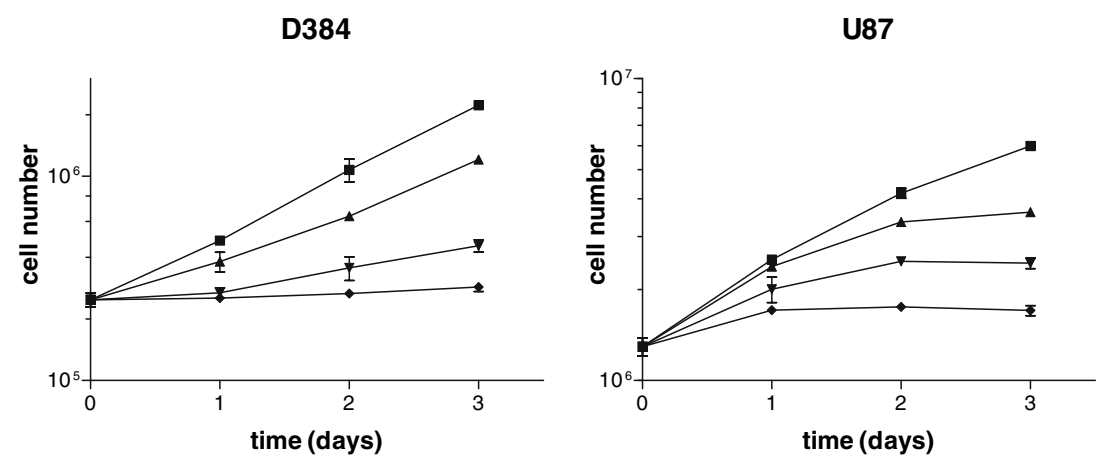

U251

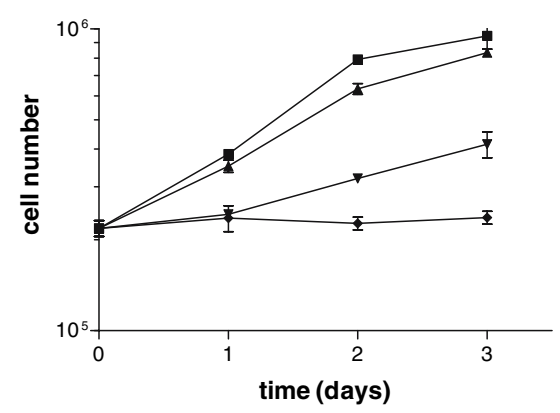

\section{.}


Fig. 2 Radiation cell survival curves for D384 cells, U87 cells and U251 cells. Cells were pretreated for $24 \mathrm{~h}$ either with vehicle $(0.38 \%$ DMSO) (匹) or $750 \mu \mathrm{M}$ meloxicam $(\mathbf{\Delta})$. Error bars represent SD of three independent experiments. (n.s. is not significant)

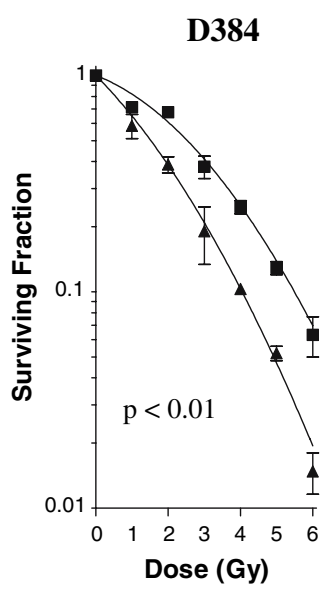

U251

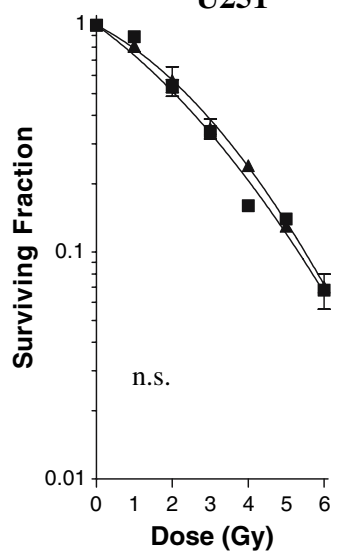

$750 \mu \mathrm{M}$ meloxicam. Following exposure to meloxicam, the fraction of $U 87$ cells in the $G_{0} / G_{1}$ phase increased from 53 to $75 \%$ (Fig. 4).

\section{Discussion}

Previous studies have demonstrated tumor growth inhibition and radioenhancement by selective inhibition of the COX-2 protein [11, 16-19, 15]. The COX-2 inhibitor meloxicam was reported to inhibit growth of various tumor cell types both in vitro and in vivo [10, 12, 22, 23, 29, 30]. Until now, neither the growth inhibitory capacity nor the radiosensitizing potential of meloxicam was tested on human glioma cells.

The present study shows that meloxicam inhibits cell growth of three glioma cell lines and significantly radiosensitizes two of them. Exposure to $750 \mu \mathrm{M}$ meloxicam almost completely suppressed cell growth, but only slightly reduced cell survival. Our observations agree with other reports, showing inhibition of cell proliferation at comparable doses of meloxicam [24, 25, 31]. Since the glioma cells we tested had different levels of constitutive COX-2 protein expression, the growth inhibitory response was probably not related to the COX-2 protein level. COX-2 independent growth inhibition has also been reported by Patel et al. [32] after treatment of human prostate cancer cells with celecoxib or rofecoxib both in vitro and in vivo.

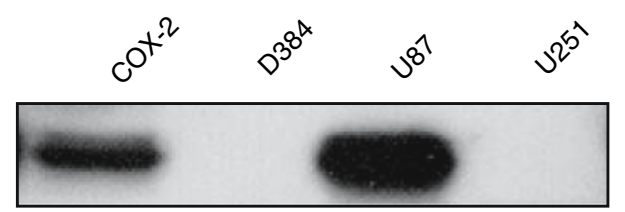

Fig. 3 Representative western blot showing COX-2 expression in D384, U87 and U251 cells relative to the reference standard
Furthermore, celecoxib was reported to inhibit growth of 9L rat gliosarcoma cells that were orthotopically transplanted in rat brains, leading to a decreased expression of Bcl-2, Bcl-XL, phosphorlyated Akt and EGFR [11]. However Hsu et al. [33] reported celecoxib to induce apoptosis by blocking the activation of anti-apoptotic Akt in prostate cancer cells via an action that was independent of Bcl-2.

Little information is available about the molecular mechanisms involved in COX-2 mediated growth inhibition. Both cell cycle blockade and induction of apoptosis are reported after in vitro exposure of cells to the inhibitors meloxicam, celecoxib and rofecoxib. The meloxicam concentration and exposure time we used in our experiments did not result in the induction of apoptosis, but caused a cell cycle arrest. Because cell cycle arrest was induced at a concentration of meloxicam higher than needed for inhibition of $\mathrm{COX}-2$ function, this effect was probably independent of the $\mathrm{COX}-2$ protein. $\mathrm{COX}-2$ independent anti-tumor effects of selective COX-2 inhibitors have recently been discussed in detail by Grosch et al. [34].

Petersen et al [17], using the COX-2 inhibitor SC-236, reported radioenhancement after treatment of $\mathrm{U} 251$ cells (DMF of 1.4 at SF 0.1 ). The absence of a radioenhancement on U251 cells in the present data (Fig. 2), might be ascribed to a different mechanism of action of the inhibitor meloxicam. Meloxicam enhanced the radiation response of D384 and U87 (Fig. 2). Because only U87 cells constitutively expressed the COX-2 protein, this observation suggests that the radiosensitizing effect was not related to the COX-2 protein level at the time of irradiation. However, using the selective COX-2 inhibitor NS-398, Pyo et al. [18] found a preference for radiosensitization of cells that express COX-2.

Cells in the $\mathrm{G}_{2} / \mathrm{M}$ phase of cell cycle are known to be sensitive to radiation [35]. Previous studies reported 
Fig. 4 FACS analysis $(n=2)$ of D384, U87 and U251 cell cycle distribution $24 \mathrm{~h}$ following exposure to $750 \mu \mathrm{M}$ meloxicam or vehicle (0.38\% DMSO). Proportions of $G_{1}, S$ - and $G_{2} / M$ phase are given in percent
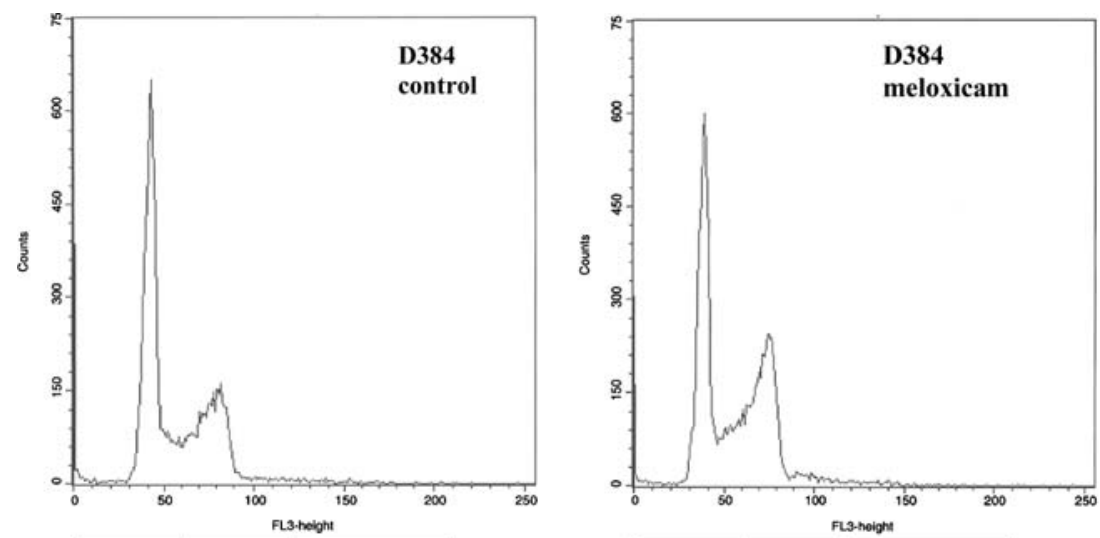

\begin{tabular}{|c|c|c|}
\hline G1 & S & G2/M \\
\hline 51 & 31 & 18 \\
\hline
\end{tabular}
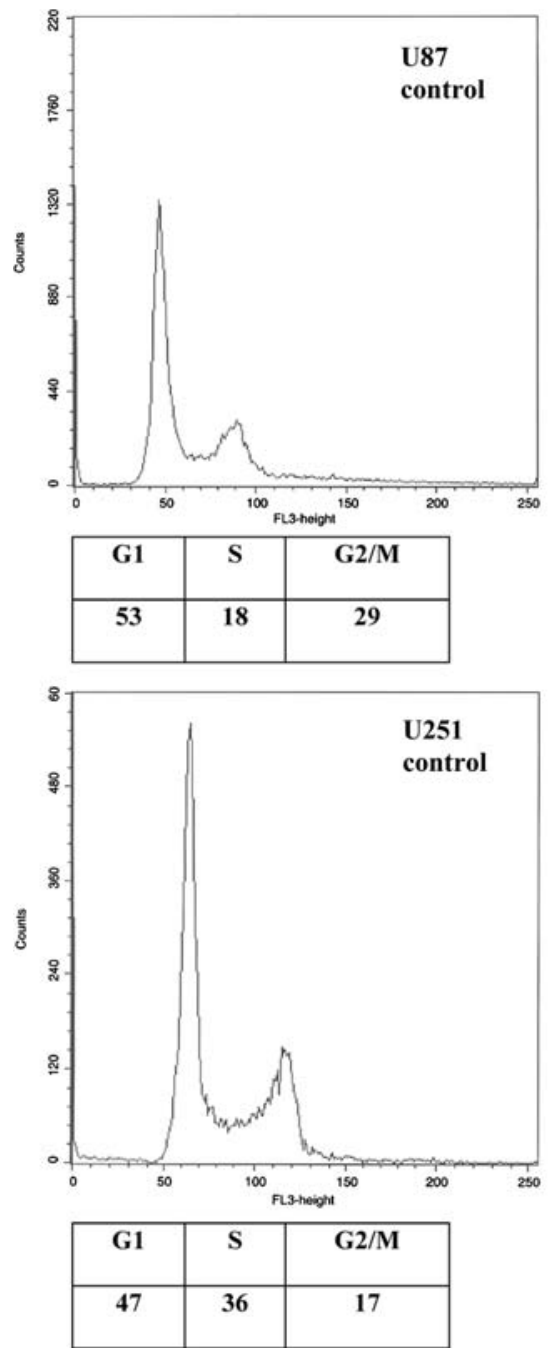
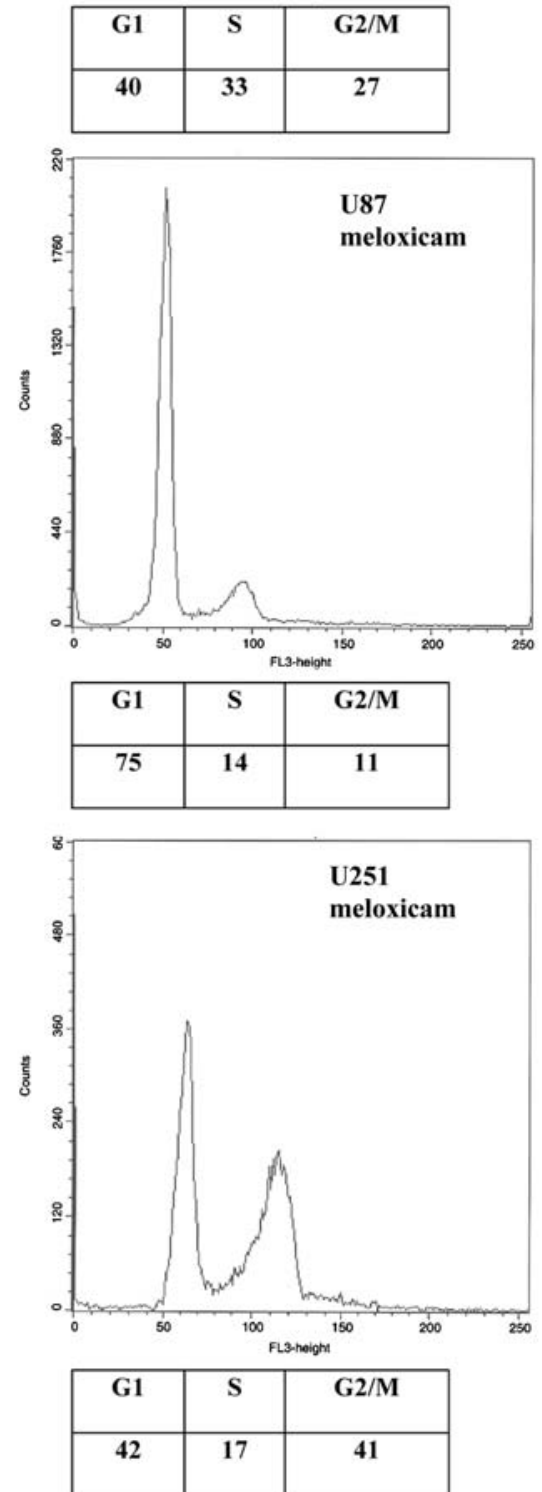

accumulation of cells into the $\mathrm{G}_{2} / \mathrm{M}$ phase by inhibitors of the COX-2 protein $[19,36]$. The radiosensitizing effect of meloxicam we observed in our experiments was probably not caused by cell cycle redistribution (cf. Figs. 2 and 4).
Growth inhibition and radiosensitization can be mediated by the prostaglandins. The COX-enzymes are the ratelimiting enzymes in the prostaglandin pathway, i.e. the conversion of arachidonic acid to prostaglandins. The 
COX-2 enzyme is responsible for the synthesis of prostaglandin subtypes involved in pathological conditions. The major metabolite of COX-2 is $\mathrm{PGE}_{2}$, which is reported to inhibit apoptosis [37] and to act as radioprotector [38, 39]. Hence, the radiosensitizing action of meloxicam might be ascribed to inhibition of the $\mathrm{PGE}_{2}$ production, as previously reported [23]. Kang et al [40] reported radiosensitization of U87 cells by celecoxib after high dose irradiation in vitro by $\mathrm{PGE}_{2}$ inhibition. This phenomenon might also explain our data, although the meloxicam concentration in our experiments was higher than reported to be required for inhibition of $\mathrm{PGE}_{2}$ production [19, 41]. Experimental studies on the growth inhibitory and radiosensitizing effects of meloxicam should focus on $\mathrm{PGE}_{2}$ synthesis and on apoptosis induction.

A recent report showed that meloxicam may exert its anticancer effect by binding of $\mathrm{Cu}(\mathrm{II})$-complexes of meloxicam with the DNA backbone, resulting in DNA distortion [42]. Further studies should attempt to determine a possible interaction of DNA-intercalated $\mathrm{Cu}(\mathrm{II})$-meloxicam complexes with irradiation and the effect on the induction and repair of DNA damage.

The present findings on three human glioma cell lines demonstrate that the COX-2 inhibitor meloxicam inhibits cell proliferation and may enhance the radiation response, independent of COX-2 protein expression. Because of the radiosensitizing potential of meloxicam and in view of the recently reported interaction between irradiation and celecoxib [40] as well as between temozolomide and celecoxib [43] in experimental gliomas, selective COX-2 inhibitors yield promising perspective to further improve the therapy of glioma patients.

Acknowledgements Boehringer Ingelheim (Germany) is kindly acknowledged for providing meloxicam

\section{References}

1. Brada M (1999) Current approaches to radiation therapy for malignant gliomas. Front Radiat Ther Oncol 33:139-149

2. Hulshof MC, Koot RW, Schimmel EC, Dekker F, Bosch DA, Gonzalez GD (2001) Prognostic factors in glioblastoma multiforme. 10 years experience of a single institution. Strahlenther Onkol 177:283-290

3. Slotman BJ, Kralendonk JH, van Alphen HA, Kamphorst W, Karim AB (1996) Hypofractionated radiation therapy in patients with glioblastoma multiforme: results of treatment and impact of prognostic factors. Int J Radiat Oncol Biol Phys 34:895-898

4. Stupp R, Mason WP, van den Bent MJ, Weller M, Fisher B, Taphoorn MJ, Belanger K, Brandes AA, Marosi C, Bogdahn U, Curschmann J, Janzer RC, Ludwin SK, Gorlia T, Allgeier A, Lacombe D, Cairncross JG, Eisenhauer E, Mirimanoff RO (2005) Radiotherapy plus concomitant and adjuvant temozolomide for glioblastoma. N Engl J Med 352:987-996
5. Choy H, Milas L (2003) Enhancing radiotherapy with cyclooxygenase- 2 enzyme inhibitors: a rational advance? J Natl Cancer Inst 95:1440-1452

6. Shono T, Tofilon PJ, Bruner JM, Owolabi O, Lang FF (2001) Cyclooxygenase-2 expression in human gliomas: prognostic significance and molecular correlations. Cancer Res 61:43754381

7. Khuri FR, Wu H, Lee JJ, Kemp BL, Lotan R, Lippman SM, Feng L, Hong WK, Xu XC (2001) Cyclooxygenase-2 overexpression is a marker of poor prognosis in stage I non-small cell lung cancer. Clin Cancer Res 7:861-867

8. New P (2004) Cyclooxygenase in the treatment of glioma: its complex role in signal transduction. Cancer Control 11:152-164

9. Sminia P, Stoter TR, van der Valk P, Elkhuizen PH, Tadema TM, Kuipers GK, Vandertop WP, Lafleur MV, Slotman BJ (2005) Expression of cyclooxygenase-2 and epidermal growth factor receptor in primary and recurrent glioblastoma multiforme. $\mathrm{J}$ Cancer Res Clin Oncol 131:653-661

10. Kern MA, Schoneweiss MM, Sahi D, Bahlo M, Haugg AM, Kasper HU, Dienes HP, Kaferstein H, Breuhahn K, Schirmacher $P$ (2004) Cyclooxygenase-2 inhibitors suppress the growth of human hepatocellular carcinoma implants in nude mice. Carcinogenesis 25:1193-1199

11. Nam DH, Park K, Park C, Im YH, Kim MH, Lee S, Hong SC, Shin HJ, Kim JH, Eoh W, McDonnell TJ (2004) Intracranial inhibition of glioma cell growth by cyclooxygenase- 2 inhibitor celecoxib. Oncol Rep 11:263-268

12. Tsuchida A, Itoi T, Kasuya K, Endo M, Katsumata K, Aoki T, Suzuki M, Aoki T (2005) Inhibitory effect of meloxicam, a cyclooxygenase-2 inhibitor, on N-nitrosobis (2-oxopropyl) amine induced biliary carcinogenesis in Syrian hamsters. Carcinogenesis 26:1922-1928

13. Dempke W, Rie C, Grothey A, Schmoll HJ (2001) Cyclooxygenase-2: a novel target for cancer chemotherapy? J Cancer Res Clin Oncol 127:411-417

14. Sanchez-Alcazar JA, Bradbury DA, Pang L, Knox AJ (2003) Cyclooxygenase (COX) inhibitors induce apoptosis in non-small cell lung cancer through cyclooxygenase independent pathways. Lung Cancer 40:33-44

15. Amirghahari N, Harrison L, Smith M, Rong X, Naumann I, Ampil F, Shi R, Glass J, Nathan CA (2003) NS 398 radiosensitizes an HNSCC cell line by possibly inhibiting radiation-induced expression of COX-2. Int J Radiat Oncol Biol Phys 57:14051412

16. Liu W, Chen Y, Wang W, Keng P, Finkelstein J, Hu D, Liang L, Guo M, Fenton B, Okunieff P, Ding I (2003) Combination of radiation and celebrex (celecoxib) reduce mammary and lung tumor growth. Am J Clin Oncol 26:S103-S109

17. Petersen C, Petersen S, Milas L, Lang FF, Tofilon PJ (2000) Enhancement of intrinsic tumor cell radiosensitivity induced by a selective cyclooxygenase-2 inhibitor. Clin Cancer Res 6:25132520

18. Pyo H, Choy H, Amorino GP, Kim JS, Cao Q, Hercules SK, DuBois RN (2001) A selective cyclooxygenase-2 inhibitor, NS398 , enhances the effect of radiation in vitro and in vivo preferentially on the cells that express cyclooxygenase-2. Clin Cancer Res 7:2998-3005

19. Raju U, Nakata E, Yang P, Newman RA, Ang KK, Milas L (2002) In vitro enhancement of tumor cell radiosensitivity by a selective inhibitor of cyclooxygenase-2 enzyme: mechanistic considerations. Int J Radiat Oncol Biol Phys 54:886-894

20. Sminia P, Kuipers G, Geldof A, Lafleur V, Slotman B (2005) COX-2 inhibitors act as radiosensitizer in tumor treatment. Biomed Pharmacother. 2(59 Suppl):S272-S275 
21. Milas L (2001) Cyclooxygenase-2 (COX-2) enzyme inhibitors as potential enhancers of tumor radioresponse. Semin Radiat Oncol 11:290-299

22. Goldman AP, Williams CS, Sheng H, Lamps LW, Williams VP, Pairet M, Morrow JD, DuBois RN (1998) Meloxicam inhibits the growth of colorectal cancer cells. Carcinogenesis 19:2195-2199

23. Tsubouchi Y, Mukai S, Kawahito Y, Yamada R, Kohno M, Inoue K, Sano H (2000) Meloxicam inhibits the growth of non-small cell lung cancer. Anticancer Res 20:2867-2872

24. Wolfesberger B, Walter I, Hoelzl C, Thalhammer JG, Egerbacher M (2006) Antineoplastic effect of the cyclooxygenase inhibitor meloxicam on canine osteosarcoma cells. Res Vet Sci 80:308316

25. Wolfesberger B, Hoelzl C, Walter I, Reider GA, Fertl G, Thalhammer JG, Skalicky M, Egerbacher M (2006) In vitro effects of meloxicam with or without doxorubicin on canine osteosarcoma cells. J Vet Pharmacol Ther 29:15-23

26. Ponten J, Westermark B (1978) Properties of human malignant glioma cells in vitro. Med Biol 56:184-193

27. Balmforth AJ, Ball SG, Freshney RI, Graham DI, McNamee HB, Vaughan PF (1986) D-1 dopaminergic and beta-adrenergic stimulation of adenylate cyclase in a clone derived from the human astrocytoma cell line G-CCM. J Neurochem 47:715-719

28. van Bree C, Rodermond HM, de VJ, Haveman J, Franken NA (2005) Mismatch repair proficiency is not required for radioenhancement by gemcitabine 105. Int J Radiat Oncol Biol Phys 62:1504-1509

29. Dohmen K, Okabe H, Ishibashi H (2006) Regression of hepatocellular carcinoma due to cyclooxygenase (COX)-2 inhibitor. Am J Gastroenterol 101:2437-2438

30. Kern MA, Haugg AM, Eiteneuer E, Konze E, Drebber U, Dienes HP, Breuhahn K, Schirmacher P, Kasper HU (2006) Ex vivo analysis of antineoplastic agents in precision-cut tissue slices of human origin: effects of cyclooxygenase- 2 inhibition in hepatocellular carcinoma. Liver Int 26:604-612

31. Yamazaki R, Kusunoki N, Matsuzaki T, Hashimoto S, Kawai S (2002) Selective cyclooxygenase-2 inhibitors show a differential ability to inhibit proliferation and induce apoptosis of colon adenocarcinoma cells. FEBS Lett 531:278-284

32. Patel MI, Subbaramaiah K, Du B, Chang M, Yang P, Newman RA, Cordon-Cardo C, Thaler HT, Dannenberg AJ (2005) Celecoxib inhibits prostate cancer growth: evidence of a cyclooxy- genase-2-independent mechanism. Clin Cancer Res 11:1999_ 2007

33. Hsu AL, Ching TT, Wang DS, Song X, Rangnekar VM, Chen CS (2000) The cyclooxygenase-2 inhibitor celecoxib induces apoptosis by blocking Akt activation in human prostate cancer cells independently of Bcl-2. J Biol Chem 275:11397-11403

34. Grosch S, Maier TJ, Schiffmann S, Geisslinger G (2006) Cyclooxygenase-2 (COX-2)-independent anticarcinogenic effects of selective COX-2 inhibitors. J Natl Cancer Inst 98:736-747

35. Sinclair WK, Morton RA (1966) X-ray sensitivity during the cell generation cycle of cultured Chinese hamster cells. Radiat Res 29:450-474

36. Furuta Y, Hunter N, Barkley T Jr, Hall E, Milas L (1988) Increase in radioresponse of murine tumors by treatment with indomethacin. Cancer Res 48:3008-3013

37. Zimmermann KC, Sarbia M, Weber AA, Borchard F, Gabbert HE, Schror K (1999) Cyclooxygenase-2 expression in human esophageal carcinoma. Cancer Res 59:198-204

38. Hanson WR, DeLaurentiis K (1987) Comparison of in vivo murine intestinal radiation protection by E-prostaglandins. Prostaglandins 33(Suppl):93-104

39. Zaffaroni N, Villa R, Orlandi L, De PA, Del MS, Silvestrini R (1993) Differential effect of 9 beta-chloro-16, 16-dimethyl prostaglandin E2 (nocloprost) on the radiation response of human normal fibroblasts and colon adenocarcinoma cells. Radiat Res 135:88-92

40. Kang K, Wang T, Woon C, Cheah E, Path F, Moore X, Zhu C, Wong M (2007) Enhancement of glioblastoma radioresponse by a selective COX-2 inhibitor celecoxib: inhibition of tumor angiogenesis with extensive tumor necrosis. Int J Radiat Oncol Biol Phys 67:888-896

41. Tegeder I, Pfeilschifter J, Geisslinger G (2001) Cyclooxygenaseindependent actions of cyclooxygenase inhibitors. FASEB J 15:2057-2072

42. Roy S, Banerjee R, Sarkar M (2006) Direct binding of Cu(II)complexes of oxicam NSAIDs with DNA backbone. J Inorg Biochem 100:1320-1331

43. Kang SG, Kim JS, Park K, Kim JS, Groves MD, Nam DH (2006) Combination celecoxib and temozolomide in C6 rat glioma orthotopic model. Oncol Rep 15:7-13 